\title{
Implementasi Ekstraksi Fitur untuk Pengelompokan Berkas Musik Berdasarkan Kemiripan Karakteristik Suara
}

\author{
Ramadhan Rosihadi Perdana, Rully Soelaiman, dan Chastine Fatichah \\ Jurusan Teknik Informatika, Fakultas Teknologi Informasi, Institut Teknologi Sepuluh Nopember (ITS) \\ Jl. Arief Rahman Hakim, Surabaya 60111 Indonesia \\ e-mail: ramadhanrperdana@gmail.com,rully130270@gmail.com, chastine@cs.its.id
}

\begin{abstract}
Abstrak - Pengelompokkan musik berdasarkan karakteristik suara merupakan hal penting bagi penikmat musik.. Penikmat musik tidaklah mencari musik berdasarkan artis tetapi juga mencari musik berdasarkan genre yang diinginkannya. Karena itu dibutuhkan metode ekstraksi fitur yang tepat untuk dapat merepresentasikan berkas musik berdasarkan genre dengan baik. Studi ini melakukan ekstraksi fitur berkas musik. Dengan mengekstraksi fitur spectral centroid, spectral flux, spectral rolloff, dan short time energy pada tiap berkas musik yang diolah dan kemudian dihitung nilai mean, median, skewness, dan kurtosisnya. Dan selanjutnya dikelompokkan menggunakan metode klasifikasi Random Forest dengan alat bantu Weka untuk menguji kelayakan fitur yang dihasilkan. Uji coba dilakukan dengan menggunakan kombinasi nilai atribut komponen ekstraksi fitur dan berkas musik yang berbeda-beda sesuai genre. Hasil uji coba klasifikasi pada Studi ini menghasilkan nilai akurasi terbaik sebesar $80.4 \%$.
\end{abstract}

Kata Kunci- Ekstraksi Fitur Audio, Musik, Klasifikasi, Data Sinyal

\section{PENDAHULUAN}

$\mathrm{M}$ USIK memiliki karakteristik yang berbeda antara satu dengan lainnya. Penggunaan musik berdasarkan genre telah digunakan pada kehidupan sehari-hari. Ketika terdapat sekumpulan berkas musik dalam jumlah yang besar, akan merepotkan untuk secara manual menggolongkannya kedalam kelompok-kelompok berdasarkan kesamaan karakteristik yang dimiliki tiap berkas. Melihat pesatnya industri musik sekarang dan jumlah berkas musik yang terus bertambah tiap waktu, maka pengelompokkan berkas musik berdasarkan genre diperlukan.

Sebelum proses pengelompokan dilakukan, perlu terlebih dahulu melakukan proses ekstraksi fitur guna mendapatkan nilai-nilai atribut tiap berkas musik yang akan menjadi nilai pembeda satu berkas dengan berkas lainnya. Fitur yang diekstraksi haruslah komprehensif, padat, dan efektif. Berkas musik yang terkelompokkan dalam genre yang sama berarti mereka memiliki karakteristik yang mirip, karena musikmusik tersebut dimainkan oleh alat musik yang mirip, mempunyai pola irama, dan distribusi nada yang mirip. Fitur yang diekstraksi dalam pengerjaan studi ini adalah fitur spectral centroid, spectral flux, spectral rolloff, spectral flatness, dan short time energy. Penulis menggunakan referensi metode ekstraksi fitur dari Babu et al [1] sebagai referensi utama. Keseluruhan fitur tersebut akan diambil nilai rata-rata, deviasi standar, kurtosis, dan skewnessnya sebagai atribut.

Adapun hasil yang diharapkan adalah tingginya tingkat akurasi hasil pengelompokkan. Sehingga pendekatan metode ekstraksi fitur yang digunakan pada makalah ini dapat digunakan sebagai metode alternatif untuk ekstraksi fitur dan pengelompokkan musik berdasarkan genre.

\section{METODE PENELITIAN}

\section{A. Desain Sistem}

Bagian ini merupakan desain sistem secara umum. Pada sistem ini terdapat beberapa tahap, yaitu tahap pra proses, tahap ekstraksi fitur, dan tahap uji coba klasifikasi.

Pada tahap pra proses dilakukan proses pengambilan data sampel dari berkas musik mp3 [2] yang akan diolah, kemudian dilanjutkan dengan pembagian data sampel kedalam bagian-bagian yang lebih kecil dengan ukuran sama yang biasa disebut dengan frame. Panjang frame ditentukan oleh nilai sample rate yang didapat pada proses pembacaan berkas mp3. Data yang diolah pada tahap pra proses diambil dari website http://freemusicarchive.org [3]. Data sampel yang ada, difilter terlebih dahulu menggunakan hamming window [5]. Selanjutnya dilakukan transformasi menggunakan metode transformasi fourier [4].

Tahap ekstraksi fitur, merupakan tahapan dilakukannya pengambilan nilai 6 fitur pada tiap data frame yang terbentuk kemudian dilakukan pengambilan nilai mean, standard deviasi, kurtosis, dan skewness sehingga pada satu berkas mp3 yang diekstraksi, didapatkan 24 atribut [1].

Tahap klasifikasi, merupakan tahapan yang dilakukan untuk menguji hasil ekstraksi fitur dalam merepresentasikan lagu berdasarkan genre yang dimiliki. Data nilai atribut yang dihasilkan pada tahapan ekstraksi fitur akan digunakan sebagai data training dan data testing untuk dilakukan klasifikasi pada tahapan ini dengan menggunakan metode klasifikasi Random Forest [6] guna mengetahui kelayakan fitur yang dihasilkan untuk mengkelompokkan berkas musik berdasarkan genre. Gambaran umum sistem pada makalah ini ditunjukkan pada Gambar 1. 


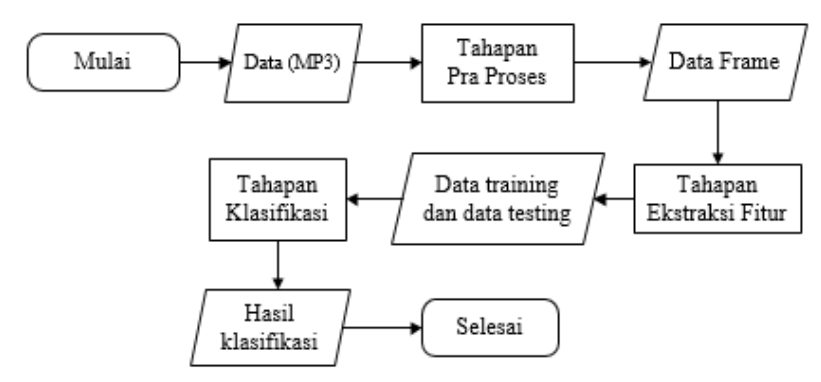

Gambar 1. Diagram Alir Desain Sistem Utama

\section{B. Tahap Pra Proses}

Pra proses merupakan proses yang dilakukan di awal pada aplikasi ini. Masukkan dari tahapan ini berupa berkas mp3 yang telah diketahui jenis genrenya, dan keluarannya berupa data sampel, sample rate, dan data sampel yang telah dibagibagi kedalam bagian lebih kecil yang disebut dengan frame.

Pada tahap pra proses dilakukan proses pengambilan data sampel dari berkas musik yang akan diolah, kemudian dilanjutkan dengan pembagian data sampel kedalam bagianbagian yang lebih kecil dengan ukuran sama yang biasa disebut dengan frame. Panjang frame ditentukan oleh nilai sampel rate yang didapat pada proses pembacaan berkas mp3.

Penentuan nilai step dilakukan pada tahapan ini guna menentukan tipe data fragmen yang dibentuk, apakah ingin dikehendaki data bersifat overlap dengan data fragmen tetangganya, ataukah tidak. Diagram alir proses pengerjaan pada tahapan Pra Proses ditunjukkan pada Gambar 2.

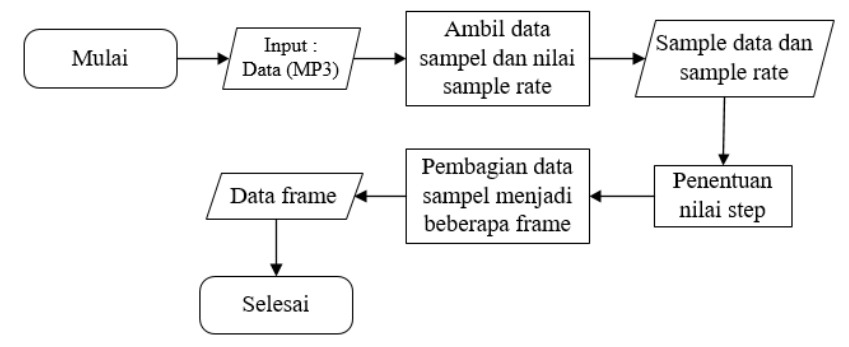

Gambar 2. Diagram alir tahapan pra proses

\section{Tahap Ekstraksi Fitur}

Ekstraksi fitur merupakan proses awal pada aplikasi ini. Terdapat tujuh subproses di dalam tahapan ekstraksi fitur, yang masing-masing merupakan proses perhitungan fitur. Sebelum dilakukan perhitungan untuk mengekstraksi fitur, program mengambil sample data dan sample rate terlebih dahulu pada berkas musik yang akan diolah.

Dari sample data dan sample rate yang didapat, proses perhitungan nilai fitur pada makalah ini dilakukan pada tiap frame dengan panjang frame ditentukan sebanyak $0.01 \mathrm{x}$ sample rate data yang sama dengan banyak sample data pada berkas musik selama 10 mikro detik. Selisih panjang data yang dilewati antar posisi awal suatu frame dengan posisi awal frame selanjutnya dinamakan dengan step.
Setelah perhitungan nilai enam fitur pada tiap frame selesai dilakukan, maka dihitung empat nilai statistikalnya untuk masing-masing fitur. Empat nilai statistikal yang dihitung pada tiap fitur adalah mean, deviasi standar, skewness, dan kurtosis. Sehingga output dari tahapan ini menghasilkan 24 atribut yang digunakan sebagai data training dan data testing pada tahapan klasifikasi. Diagram alir proses pengerjaan pada tahapan ekstraksi fitur ditunjukkan pada Gambar 3.

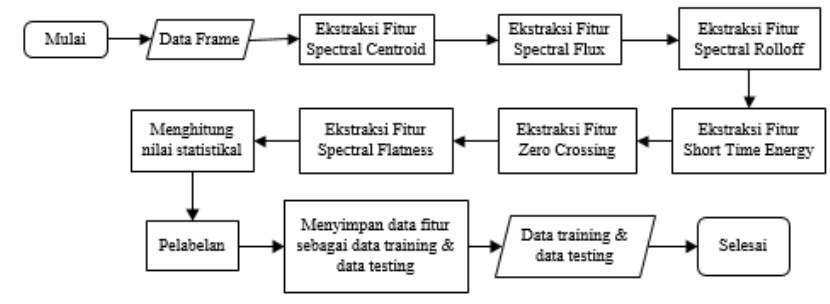

Gambar 3. Diagram alir tahapan ekstraksi fitur

\section{Tahap Klasifikasi}

Salah satu tahapan pada makalah ini yaitu proses klasifikasi. Pada makalah ini, proses klasifikasi untuk menentukan genre pada berkas musik dilakukan menggunakan metode klasifikasi Random Forest dan memakai alat bantu Weka versi 3.8. Dataset yang digunakan berformat .ARFF dan merupakan keluaran pada proses ekstraksi fitur yang sebelumnya dilakukan.

Untuk melakukan proses klasifikasi dengan metode Random Forest menggunakan alat bantu Weka, dimulai dengan menyiapkan data training dan data testing terlebih dahulu. Saat dilakukan proses training, data training yang telah disiapkan digunakan sebagai data sampel. Kemudian dilakukan pengaturan parameter algoritma Random Forest yang tersedia pada alat bantu Weka.

Setelah parameter selesai diatur, barulah algoritma klasifikasi Random Forest dijalankan dengan menggunakan data training yang telah disiapkan dari hasil tahapan ekstraksi fitur. Alat bantu Weka akan menampilkan hasil trainingnya, kemudian barulah dilanjutkan proses testing. Proses testing dilakukan dengan menggunakan data testing yang telah dipersiapkan sebelumnya dari hasil tahapan ekstraksi fitur sebagai data tes. Selanjutnya algoritma klasifikasi Random Forest dijalankan kembali untuk proses testing. Alat bantu aplikasi Weka kemudian akan menampilkan hasil testing berupa nilai akurasi yang didapatkan dan juga tabel confussion matrix.

\section{HASIL DAN DISKUSI}

Lingkungan pengujian sistem ini dilakukan dengan menggunakan alat kakas sebuah laptop dengan spesifikasi prosessor Intel ${ }^{\circledR}$ Core ${ }^{\mathrm{TM}}$ i5 CPU @ $2.40 \mathrm{GHz}$ dengan RAM sebesar 8.0 GB.

Data yang digunakan untuk pengujian merupakan berkas MP3 yang diunduh dari website http://freemusicarchive.org. Data pengujian dibagi menjadi dua yaitu data untuk training, dan data untuk testing. Terdapat 70 berkas musik tiap genre untuk data training, dan 30 berkas musik tiap genre untuk data testing. 
Terdapat 3 pengujian, yaitu perbandingan nilai akurasi hasil klasifikasi berdasarkan panjang step yang digunakan pada saat proses ekstraksi fitur, perbandingan hasil akurasi berdasarkan kombinasi data genre, dan perbandingan hasil akurasi berdasarkan metode klasifikasi yang digunakan.

\section{A. Perbandingan nilai akurasi berdasarkan panjang step yang digunakan}

Uji coba dilakukan dengan membandingkan nilai step yang digunakan ketika melakukan proses ekstraksi fitur. Uji coba ini dilakukan dengan tujuan untuk mengevaluasi nilai akurasi atau nilai kebenaran dari perbedaan nilai step yang digunakan, yang mana nilai step ini mempengaruhi nilai fitur tiap file musik pada saat proses ekstraksi fitur. Dengan kata lain, hasil dari uji coba skenario ini adalah berupa nilai step terbaik yang kemudian akan digunakan sebagai acuan untuk proses uji coba selanjutnya.

Istilah step pada Studi ini menunjukkan jarak data antara titik awal frame satu ke titik awal frame selanjutnya dalam satuan presentase panjang frame. Step yang nilainya kurang dari panjang frame menyebabkan data yang diolah menjadi tumpang tindih.

Uji coba perbandingan hasil akurasi berdasarkan nilai step pada proses ekstraksi fitur musik dilakukan dengan menggunakan 700 file musik sebagai data training, dan 300 file musik sebagai data testing yang diambil dari website http://freemusicarchive.org. Uji coba dilakukan dengan membandingkan dua nilai step, yakni 0.5 dan 1 . Uji coba pada skenario pertama ini menggunakan data musik dengan genre classical, country, hip hop, jazz, metal, pop, dan rock.

Kemudian dilakukan proses training menggunakan alat bantu Weka dengan metode Random Forest. Data training dan data testing menggunakan data yang telah disiapkan di awal. Perbandingan hasil akurasi dari setiap kombinasi data berdasarkan genre ditunjukkan pada Tabel 1 .

Tabel 1.Perbandingan nilai akurasi hasil klasifikasi berdasarkan nilai step yang digunakan

\begin{tabular}{ccc}
\hline \hline No & Nilai Step & Nilai Akurasi \\
\hline 1 & 0,5 & $72.8571 \%$ \\
2 & 1 & $80 \%$ \\
\hline \hline
\end{tabular}

Pada step dengan nilai 0.5 , menghasilkan nilai akurasi kebenaran lebih kecil jika dibandingkan dengan nilai step 1, yakni sebesar $80 \%$. Dengan kata lain, hasil akurasi terbaik dicapai dengan menggunakan nilai step pada saat ekstraksi fitur sebesar 1.

\section{B. Perbandingan Nilai Akurasi Berdasarkan Kombinasi Data Genre}

Pada skenario ini dilakukan uji coba dengan membandingkan beberapa kombinasi genre musik yang dilibatkan saat proses klasifikasi. Tujuan dilakukannya uji coba adalah untuk mengevaluasi nilai akurasi atau nilai kebenaran berdasarkan kombinasi data musik berdasarkan genre yang dilibatkan pada data training dan data testing, sehingga dapat diketahui kombinasi genre apa saja yang paling cocok untuk direpresentasikan dengan metode ekstraksi fitur pada makalah ini. Uji coba ini menggunakan kombinasi dari 1000 buah berkas musik dengan 10 genre yaitu genre musik blues, classical, country, disco, hiphop, jazz, metal, pop, reggae, dan rock yang diunduh dari website http://freemusicarchive.org. Uji coba perbandingan dilakukan dengan tujuan untuk mengevaluasi kombinasi genre apa saja yang paling sesuai untuk fitur yang telah diekstraksi. Dengan kata lain hasil dari uji coba adalah berupa kombinasi genre terbaik yang kemudian akan digunakan sebagai acuan untuk proses uji coba selanjutnya.

Uji coba perbandingan hasil akurasi berdasarkan kombinasi data genre yang digunakan pada data training dan data testing dilakukan dengan menggunakan 700 file musik sebagai data training, dan 300 file musik sebagai data testing yang diambil dari website http://freemusicarchive.org. Dan didasarkan pada hasil uji coba sebelumnya, maka besar step yang digunakan adalah 1.

Uji coba pada ini dilakukan dengan membandingkan nilai akurasi hasil klasifikasi terhadap sekumpulan data musik dengan 2 kombinasi genre. Kombinasi genre 1 adalah genre classical, country, hiphop, jazz, metal, pop, dan rock Dan kombinasi genre 2 meliputi data dengan genre blues, country, disco, jazz, metal, pop, reggae.

Tabel 2. Perbandingan nilai akurasi hasil klasfikasi berdasarkan kombinasi data yang digunakan

\begin{tabular}{ccc}
\hline \hline No & Kombinasi Genre & Nilai Akurasi \\
\hline 1 & Classical, country, hiphop, jazz, metal, pop, & $80 \%$ \\
& $\begin{array}{c}\text { dan rock } \\
2\end{array}$ & $\begin{array}{c}\text { Blues, country, disco, jazz, metal, pop, } \\
\text { reggae. }\end{array}$ \\
\hline \hline
\end{tabular}

Setelah proses training dilakukan menggunakan alat bantu Weka dengan metode Random Forest. Data training dan data testing menggunakan data yang telah disiapkan di awal.

Perbandingan hasil akurasi dari setiap kombinasi data berdasarkan genre ditunjukkan pada Tabel 2. Pada Kombinasi Genre 1, ditunjukkan bahwa hasil klasifikasi memiliki nilai akurasi kebenaran lebih besar jika dibandingkan dengan kombinasi genre lainnya, yakni sebesar $80 \%$. Dengan kata lain, hasil akurasi terbaik dicapai dengan menggunakan kombinasi data genre 1, yakni genre classical, country, hiphop, jazz, metal, pop, rock.

\section{Perbandingan Nilai Akurasi Berdasarkan Metode Klasifikasi yang Digunakan}

Pada skenario ini dilakukan uji coba dengan membandingkan nilai akurasi hasil ekstraksi fitur yang dilakukan dengan beberapa metode klasifikasi. Tujuan dilakukannya uji coba adalah untuk membandingkan nilai akurasi atau nilai kebenaran hasil ekstraksi fitur dengan metode klasifikasi naive bayes, random forest, multi layer perceptron, support vector machine, dan J48. Uji coba skenario 3 ini menggunakan kombinasi dari 1000 buah berkas musik dengan 7 genre yaitu genre musik classical, country, hiphop, jazz, metal, pop, rock yang diunduh dari website http://freemusicarchive.org. Uji coba perbandingan dilakukan 
dengan tujuan untuk metode klasifikasi mana yang paling sesuai untuk fitur yang telah diekstraksi. Dengan kata lain hasil dari uji coba skenario adalah berupa nilai akurasi dari hasil klasifikasi dengan metode naive bayes, random forest, multi layer perceptron, support vector machine, dan J48.

Perbandingan hasil akurasi dari setiap kombinasi data berdasarkan genre ditunjukkan pada Tabel 3. Dari tabel tersebut ditunjukkan bahwa metode klasifikasi Naïve Bayes menghasilkan nilai akurasi tertinggi sebesar $80.4672 \%$ dan dilanjutkan dengan metode random forest dengan nilai akurasi $80 \%$.

Tabel 3. Perbandingan nilai akurasi hasil klasifikasi berdasarkan metode klasifikasi yang digunakan

\begin{tabular}{ccc}
\multicolumn{3}{c}{ klasifikasi yang digunakan } \\
\hline \hline No & Metode Klasifikasi & Nilai Akurasi \\
\hline 1 & Naïve Bayes & 80.4762 \\
2 & Random Forest & 80 \\
3 & Multi Layer Perceptron & 77.619 \\
4 & Support Vector Machine & 69.5238 \\
5 & J48 & 62.8571 \\
\hline \hline
\end{tabular}

\section{KESIMPULAN/RINGKASAN}

Dari hasil Dari hasil uji coba yang telah dilakukan terhadap pembuatan program ekstraksi fitur musik berdasarkan genre dapat diambil kesimpulan sebagai berikut :

1. Fitur yang dihasilkan saat proses ekstraksi fitur musik pada Studi ini mampu merepresentasikan musik berdasarkan genre dengan baik, terbukti dengan nilai akurasi dengan prosentase $80.4762 \%$ ketika diklasifikasi dengan metode naïve bayes.

2. Dalam kasus pengelompokkan berkas musik berdasarkan genre, nilai step = 1 merupakan yang paling bagus jika dibandingkan dengan nilai step yang lain ketika digunakan saat proses ekstraksi fitur untuk menghasilkan akurasi yang tinggi.

\section{DAFTAR PUSTAKA}

[1] D. G. J. L. Babu Kaji Baniya, "Automatic Music Genre Classification Using Timbral Texture and Rhythmic Content Features," ICACT Transactions on Advanced Communications Technology (TACT), vol. 3, no. 3, 2014.

[2] M. Rouse, "WhatIs.com," [Online]. Available: http://whatis.techtarget.com/definition/MP3-MPEG-1-Audio-Layer-3. [Accessed 121 2017].

[3] "The Free Music Archive," [Online]. Available: http://freemusicarchive.org/. [Accessed 512 2016].

[4] "Fast Fourier Transform - MATLAB \& Simulink," [Online]. Available: https://www.mathworks.com/help/matlab/ref/fft.html. [Accessed 1412 2016].

[5] "Hamming Window - MATLAB hamming," [Online]. Available: https://www.mathworks.com/help/signal/ref/hamming.html. [Accessed 1412 2016].

[6] L. Breiman and A. Cutler, "Statistics at UC Berkeley, Department of Statistics," [Online]. Available: http://www.stat.berkeley.edu/ breiman/RandomForests/cc_home.htm. [Accessed 1 December 2016]. 